\title{
Author Correction to: Adjuvant Trastuzumab Therapy for Early HER2-Positive Breast Cancer in Iran: A Cost-Effectiveness and Scenario Analysis for an Optimal Treatment Strategy
}

\author{
Amir Ansaripour ${ }^{1}$ (D) Carin A. Uyl-de Groot ${ }^{1}$ W. Ken Redekop ${ }^{1}$
}

Published online: 23 February 2018

(C) Springer International Publishing AG, part of Springer Nature 2018

\section{Author Correction to:}

PharmacoEconomics (2018) 36(1):91-103

https://doi.org/10.1007/s40273-017-0557-6

In the print publication the data in Table 2, has been incorrectly published.

Page 95, Table 2, final row, second column: the mean Advanced treatment annual cost which

previously read

83,249

should read

8324

The original article can be found online at https://doi.org/10.1007/ s40273-017-0557-6.

Amir Ansaripour

ansaripour@bmg.eur.nl

Institute for Medical Technology Assessment, Institute of

Health Policy and Management, Erasmus University

Rotterdam, PO Box 1738, 3000 DR Rotterdam, The

Netherlands 